\title{
Determinants of arbovirus vector density as a measure of transmission risk in regions of recent Zika virus introduction in the Americas
}

Benoit Talbot ( $\sim$ benoit.talbot@uottawa.ca )

University of Ottawa https://orcid.org/0000-0002-3567-1213

Beate Sander

University Health Network

Varsovia Cevallos

Instituto Nacional de Investigación en Salud Pública: Instituto Nacional de Investigacion en Salud

Publica

Camila González

Universidad de Los Andes

Denisse Benítez

Instituto Nacional de Investigacion en Salud Publica

Claudio Carissimo

Municipalidad de Posadas

María C. Carrasquilla Ferro

Universidad de Los Andes

Neris Gauto

Municipalidad de Posadas

Sergio Litwiñiuk

UNaM: Universidad Nacional de Misiones

Karen López

Municipalidad de Posadas

Mario I. Ortiz

Universidad de Los Andes

\section{Patricio Ponce}

Instituto Nacional de Investigacion en Salud Publica

Stephany D. Villota

Instituto Nacional de Investigacion en Salud Publica

\section{Fabian Zelaya}

Municipalidad de Posadas

\section{Mauricio Espinel}

Universidad Laica Eloy Alfaro de Manabí: Universidad Laica Eloy Alfaro de Manabi 


\section{Jianhong Wu}

York University

\section{Marcos Miretti}

UNaM: Universidad Nacional de Misiones

\section{Manisha A. Kulkarni}

University of Ottawa

\section{Research}

Keywords: Disease risk, Global health, Mosquito vector, Socio-economic status, Wealth Index, Wealth inequality.Disease risk, Global health, Mosquito vector, Socio-economic status, Wealth Index, Wealth inequality

Posted Date: May 10th, 2021

DOI: https://doi.org/10.21203/rs.3.rs-419833/v1

License: (c) (i) This work is licensed under a Creative Commons Attribution 4.0 International License. Read Full License 


\section{Abstract}

\section{Background}

The global impact of Zika virus in Latin America and the Caribbean has drawn renewed attention to circulating mosquito-borne viruses in this region, such as dengue and chikungunya. Our objective was to assess socio-ecological factors associated with Aedes mosquito vector density as a measure of arboviral transmission risk in three cities of potential recent Zika virus introduction: Ibagué, Colombia; Manta, Ecuador; and Posadas, Argentina, in order to inform disease mitigation strategies.

\section{Methods}

We monitored Aedes mosquito populations over 12 months starting in 2018 in a total of 1,086 randomly selected households, using indoor and peridomestic mosquito collection methods. For each sampled household, we collected socio-economic data using structured questionnaires and data on microenvironmental conditions using iButton data loggers.

\section{Results}

A total of 3,230 female Aedes mosquitoes were collected, of which $99.8 \%$ were Ae. aegypti and $0.2 \%$ were Ae. albopictus. Mean female Aedes spp. mosquito abundance per household was 1.71. We modeled the interaction between neighborhood and household wealth profiles, and found significantly lower Aedes density in highest compared to lowest and middle wealth households, although the effect differed by level of neighborhood wealth. We used mixed-effects Poisson regression analyses to identify predictors of Aedes density, using month, neighborhood, and country as random-effect variables. Across study sites, the number of household occupants (Incidence rate ratio, IRR $=1.08$ ), presence of entry points for mosquitoes into the household (IRR $=1.51)$, and presence of decorative vegetation (IRR $=1.52$ ) were associated with higher Aedes density; while being in the highest wealth tertile of household wealth (IRR = $0.78)$, knowledge of how arboviruses are transmitted (IRR $=0.94)$ and regular emptying of water containers by occupants (IRR $=0.79)$ were associated with lower Aedes density.

\section{Conclusions}

Our study addresses the complexities of arbovirus vectors of global significance at the interface between society and the environment. Our results point to several determinants of Aedes mosquito vector density in countries with co-circulation of multiple Aedes-borne viruses, and could help us identify targets of practical intervention for disease prevention and control.

\section{Background}

Globalization and global environmental changes have increased the exposure of world populations to a number of emerging pathogens, including tropical mosquito-borne arboviruses [1, 2]. Among globally emerging and re-emerging arboviruses causing human disease in recent years, Zika, dengue, and 
chikungunya viruses have been of increasing regional importance in the Americas. Zika virus (Flavivirus, Flaviviridae) was historically confined to Africa and Asia [3]. In late 2014 this virus spread from the South Pacific Islands and French Polynesia and reached the Americas [4], where it was associated with severe autoimmune and neurological complications, such as Guillain-Barré syndrome and microcephaly in newborn infants [5]. Dengue virus (Flavivirus, Flaviviridae) is the cause of the most common arboviral disease that affects humans, dengue fever, which may lead to death in severe hemorrhagic fever cases [6]. Chikungunya virus (Alphavirus, Togaviridae) is associated with long-lasting arthralgia, rash and fever, and has caused outbreaks of disease in countries in Africa, Asia, and Europe [7]. In 2013, this virus emerged in the Americas in Saint-Martin, and rapidly spread throughout the Latin America and Caribbean region within a year [7].

Two mosquito species, Aedes aegypti (Linnaeus) and Aedes albopictus (Skuse), are among the world's most prominent arboviral vectors. The original geographic range of Ae. aegypti in sub-Saharan Africa was extended to the Americas and the Asia-Pacific region, when the species was introduced via ships during the European colonization period [8]. This mosquito species has since become domesticated (i.e. adapted to breed in human habitats), and is now endemic across all of these regions. The original geographic range of Ae. albopictus in Asia expanded through global trade particularly since the 1980s [9], and this mosquito species is now found across nearly half of the entire world landmass [10-12]. Ae. aegypti and $A$ e. albopictus are able to survive and establish reproducing populations if thresholds in temperature, humidity and precipitation are met $[13,14]$. Their close association to human habitations and human host specificity means they display high vector competence, infection rates and transmission rates for Zika, dengue and chikungunya viruses in the Americas [15].

The impact of urbanization and social equity on mosquito vector density and disease risk has been the subject of a large body of literature (e.g. [16-18]). While lower socio-economic status (SES) and poverty seem to be strongly associated with disease risk in general [19-21], and more specifically with mosquitoborne disease risk [18, 22], the actual relationship between Aedes mosquito density and socio-economic profile is unclear. A variety of studies interrogating this subject suggest that Aedes density is either associated with higher SES, lower SES, or not associated with socio-economic profile of neighborhoods, possibly depending on a wide range of contributing or confounding factors, including the geographic scale of the investigation [23]. In addition to differences in study location and/or study design, the discrepancy between these results could lie in the distinction between household-level wealth and neighborhood-level socio-economic profile (e.g. [22]). Neighborhood SES has been associated with factors such as public water and waste management [24] and population density [25], while householdlevel SES has been associated with the quality of household structure (e.g. presence of window screens) [22], education [26], and specific mosquito- and arbovirus-related knowledge [27], where higher socioeconomic status is generally associated with lower Aedes density. However, the presence and type of indoor and outdoor vegetation, including potted plants that are often found in and around households with higher socio-economic status, are also associated with Aedes breeding sites [28]. The complex relationship between household and neighborhood SES level needs to be investigated further in areas 
displaying geographic and temporal variations in meteorological and climatic factors in order to better understand the main determinants of Aedes vector density, and by extension, arboviral disease risk.

The Latin American region is diverse given its range of different meteorological and climatic conditions, shaped by its geography and topography, but also owing to the tremendous socio-economic inequality and variation within and among political boundaries. The impact of climatic variation on Aedes density has been demonstrated in numerous studies, for example investigating the contribution of temperature, rainfall and humidity $[13,14,29,30]$, and seasonality [31, 32]. The contribution of socio-economic variation to Aedes density has also been demonstrated in numerous studies in the region, most notably in Mexico, Colombia and Brazil [23]. While socio-economic profile was associated with Aedes density in most studies, the direction of the effect was mixed.

In this study, our first objective was to investigate the interaction between household-level wealth and neighborhood-level socio-economic profile as a driver of density of Ae. aegypti and Ae. albopictus mosquitoes in the Latin American region. We conducted the study in three cities within the region that reflect variations in meteorological, climatic and socio-economic conditions, and differences in incidence/prevalence of arboviral diseases. Our second objective was to investigate the proximal determinants of Aedes mosquito density at the household level, including factors related to household characteristics, microenvironment, crowding, water and waste management, mosquito protection behavior and arbovirus knowledge by household occupants, to identify entry points for intervention.

\section{Methods}

\section{Study sites and neighborhood selection}

We selected three study sites to represent different eco-epidemiological settings in the Latin America and Caribbean region: the cities of Ibagué, Colombia; Manta, Ecuador; and Posadas, Argentina. Ibagué is a city with approximately 500,000 inhabitants, situated in a valley of the mountainous region of the northern Andes, at an altitude of $1,285 \mathrm{~m}$, and displays a tropical rainforest climate with consistent rain and warm weather throughout the year. Manta is a Pacific coastal city with approximately 5,000 inhabitants, at $6 \mathrm{~m}$ above sea level, displaying a tropical arid climate, with hot weather and little rainfall throughout the year. Posadas is a city with approximately 400,000 inhabitants, at an altitude of $120 \mathrm{~m}$ on the shore of the Paraná river, and displays a humid subtropical climate, which varies seasonally between a hot and humid summer and a warm winter. For each study site, we defined two classes of neighborhood socio-economic status, high and low, based on government classification or available information, including population density, household crowding, household wealth, and services available. We then selected two neighborhoods representative of each class, where the implementation of household surveys and mosquito collection activities were possible in at least 96 households. Over a period of 12 months, we randomly sampled eight households/neighborhood/month in each site without replacement for the collection of household survey data and mosquito sampling, for a target sample size of 384 households per study site, or 1,152 households across the three sites. 


\section{Mosquito collection and identification}

For each sampled household, we collected information on date of sampling, and latitude and longitude of the household. We placed an iButton (Maxim Integrated Inc., San Jose, CA, USA) in a central location inside the household in the morning, for collection of average temperature and humidity data over a 24hour period. We searched for any mosquito breeding sites inside and around the household and noted their presence and type. We subsequently identified the peridomestic and intradomestic spaces of the household for mosquito sampling. The peridomestic space was defined as the outdoors areas immediately surrounding the household, and could include indoor spaces where occupants did not typically spend most of their time, such as garages, laundry rooms, etc., while the intradomestic space was defined as the indoor area where occupants spent most of the time for sleeping, cooking, eating, etc. For each household, in the peridomestic space we placed one CDC miniature light trap and one resting trap (Centre for Disease Control and Prevention, Atlanta, GA, USA), and in the intradomestic space, one BG-Sentinel2 trap equipped with a BG lure (Biogents Inc., Cambridge, MA, USA). We set all traps to collect mosquitoes for a 24-hour period. On the following day, we used a Prokopack aspirator (John W. Hock Company, Gainesville, FL, USA) to collect mosquitoes in both the intradomestic and peridomestic spaces, for 30 minutes. Finally, we brought collected mosquito samples from traps and aspirators to a local field laboratory, and we identified all Aedes spp. individuals to the species, using standard taxonomic keys [33]. Identified specimens were then stored in RNAlater (Thermo Fisher Scientific, Waltham, MA, USA) and transported to a laboratory for subsequent processing and molecular analysis for virus detection; the results of these analyses will be presented in separate papers (e.g. Carrasquilla et al., submitted for review).

\section{Household questionnaire survey, arbovirus knowledge and wealth index}

For each sampled household, we administered a survey questionnaire to the household respondent (See Additional File 1 for the complete questionnaire). The questionnaire contained categories of questions pertaining to general characteristics of the household, water availability, waste disposal, mosquito control, demographics, and arbovirus knowledge. We calculated an arbovirus knowledge score using answers from questions RK1, RK5, RK9, RK13a, RK14b and RK14c (Additional File 1). For each of these questions, a positive answer is directly related to the level of general knowledge of the respondent about the risks associated with mosquitoes in and around their household. Therefore, we summed answers for these questions, up to a maximum of six, for each household of the study, which we denoted as the arbovirus knowledge predictor. We calculated a household level wealth index using the methods of Vyas and Kumaranayake [34]. We first computed a principal components analysis, using the 'stats' package in R 3.6.0, based on household assets and whether the household had electricity service, using questions HC2 and HC5 (Additional File 1), for all sampled households of the study. We then applied rotated weights from the first principal component to respective questionnaire variables, and summed values for all variables at each household. We categorized data into tertiles to obtain three levels of household wealth across the entire dataset, which we denoted as the wealth index predictor. Neighborhoods of the 
study were initially categorized as either perceived high or low socio-economic profile, based on countryspecific definitions that varied across study sites. To compute a more objective measure of neighborhood socio-economic profile that was standardized across study sites, we calculated the proportion of households of the lowest wealth index tertile in each neighborhood, which we denoted as the neighborhood poverty predictor.

\section{Analyses of household wealth and neighborhood socio- economic profile}

To attain our first objective, we investigated the interaction effect between household wealth and neighborhood socio-economic profile to understand how these factors were associated with household female Aedes spp. mosquito abundance. Therefore, we first computed a mixed-effects generalized linear regression of the interaction between our calculated household wealth index predictor and perceived high/low neighborhood socio-economic status, and the main effects of the two variables, against captured female Aedes spp. mosquito abundance in each household, using a hierarchical random-effects term of month of sampling, nested in sampling neighborhood, nested in study site. We ran the analysis a second time, but replacing the perceived neighborhood socio-economic status predictor with our calculated neighborhood poverty predictor. For both analyses, in case of a significant association between the interaction term and household female Aedes spp. mosquito abundance, we used the methods of Searle et al. [35] to plot the effect of the interaction between the two predictors on the linear prediction of household female Aedes spp. mosquito abundance.

\section{Analyses of household and occupants characteristics}

To attain our second objective, we investigated the effect of a wide range of factors related to characteristics of the household and its occupants, on female Aedes spp. mosquito abundance. These included average temperature, average humidity, altitude, arbovirus knowledge, wealth index, neighborhood poverty, in addition to variables related to household construction, water supply and storage, waste management and breeding sites, among others (See Additional File 2 and Additional File 3 for the complete list of predictors we considered). We did not include any interaction term between household wealth index and neighborhood measures of socio-economic profile in this analysis to avoid issues with model fit and interpretation of results. We conducted a simple generalized linear regression, using the 'Ime4' package [36] in R 3.6.0, for each of the 53 predictor variables against captured household female Aedes spp. mosquito abundance, using a hierarchical random-effects term of month of sampling, nested in sampling neighborhood, nested in study site. Prior to these analyses, we subtracted the mean and divided by the standard deviation of all values for numerical variables (Additional File 2). We successively performed these analyses using datasets specific to each study site, and using the entire dataset incorporating all study sites.

We selected all predictors displaying a significant univariable association $(P<0.05)$ with Aedes spp. mosquito density, where no more than $95 \%$ of data points had the same value and no more than $75 \%$ of data was missing, to reduce issues caused by small cell size, and used these in a mixed effects 
multivariable generalized linear regression analysis, using the 'Ime4' package [36] in R 3.6.0. Again, we used a hierarchical random-effects term of month of sampling, nested in sampling neighborhood, nested in study site. To assess presence of multicollinearity in our multivariable regression models, we computed the generalized variance inflation factor $\operatorname{GVIF}^{(1 /(2 \times D f))}$, using the 'car' package [37] in R 3.6.0, for all predictors. We then iteratively dropped the predictor associated with the highest $\operatorname{GVIF}^{(1 /(2 \times D f))}$ value from the full model and reran the new regression model until all GVIF $(1 /(2 \times D f))$ values were below 2 . We then proceeded with a two-step model selection approach using the Bayesian Information Criterion (BIC), i.e. the Akaike Information Criterion using the logarithm of the number of observations as the $k$ parameter. We first reduced the dataset to remove all data points containing missing data at any of the predictors included in the full model, which is a condition for the approach when applied on mixed-effects regression models. Using the reduced dataset, we computed a BIC value for the full model and for all combinations of the full model excluding one predictor, using the 'Ime4' package [36] in R 3.6.0. We ran a new multivariable regression model, but this time excluding all predictors that, when dropped from the full model, caused a decrease of the BIC value of more than 5 . We then reapplied the same model selection approach as a second step on this new model, but dropping predictors causing a decrease of the BIC value of more than 4. Using this two-step model selection approach, we ensured that only the most important predictors were retained in the resulting final model. We ran the final model using the full dataset, and computed Incidence Rate Ratio (IRR) values, i.e. the exponents of the slope coefficients, $95 \%$ confidence intervals for the IRR values, and $P$ values for each predictor. Finally, we computed the marginal and conditional $\mathrm{R}^{2}$ of the final model, using the 'MuMIn' package [38] in R 3.6.0. We successively performed these analyses using datasets specific to each study site, and using the entire dataset incorporating all study sites.

\section{Results}

\section{Study sites and neighborhood selection}

We sampled households in 16 neighborhoods, rather than the expected 12, across the three study sites in Ibagué, Colombia; Manta, Ecuador; and Posadas, Argentina. This was due to the lower average number of households in neighborhoods of perceived high socio-economic status in Ibagué, Colombia, and Manta, Ecuador, which led us to sample households in five and three neighborhoods of perceived high socioeconomic status in these study sites, respectively. Due to incomplete survey responses by the household respondent and/or incomplete mosquito collection, we did not obtain sufficient data in 66 of the 1,152 target households. Our analysis therefore used data from a total of 1,086 households: 379 in Ibagué, Colombia; 335 in Manta, Ecuador; and 372 in Posadas, Argentina. We sampled households over a total of 12 months per study site; however, the start date of data collection differed among study sites owing to site-specific logistical constraints and availability of mosquito trap supplies: June 2018 to May 2019 in Ibagué, Colombia; March 2019 to February 2020 in Manta, Ecuador; and, January to December 2019 in Posadas, Argentina.

\section{Mosquito collection and identification}


We collected a total of 3,230 Aedes spp. mosquitoes belonging to two species, with 1,470 collected from Ibagué, Colombia; 740 from Manta, Ecuador; and 1,020 from Posadas, Argentina (Table 1). We collected seven Ae. albopictus individuals, all in Ibagué, while all 3,223 remaining individuals were Ae. aegypti. The number of collected mosquitoes varied across months of collection, where in June to September yielded smaller numbers across sites, March to May yielded larger numbers across sites, and October to February varied considerably across sites (Fig. 1). The Prokopack aspirators yielded the largest number of collected mosquitoes at each site, while BG Sentinel 2 traps yielded a few hundred captured mosquitoes at each site, and light traps and resting traps each yielded less than a hundred captured mosquitoes at each site (Fig. 2). The number of female Aedes spp. was a little more than half of all collected Aedes spp. individuals, in all study sites, and average female Aedes spp. per household was 1.11 in Manta, Ecuador; 1.80 in Posadas, Argentina; and 2.12 in Ibagué, Colombia, with an average of 1.70 (Table 1).

Table 1

Total number, number of females, and average female per household, for captured mosquitoes identified as Aedes spp. by study site.

\begin{tabular}{|c|c|c|c|}
\hline Study site & $\begin{array}{l}\text { Total Aedes } \\
\text { spp. }\end{array}$ & $\begin{array}{l}\text { Total female Aedes } \\
\text { spp. }\end{array}$ & $\begin{array}{l}\text { Average female Aedes spp. per } \\
\text { household }\end{array}$ \\
\hline $\begin{array}{l}\text { Ibagué, } \\
\text { Colombia }\end{array}$ & 1470 & 805 & 2.12 \\
\hline Manta, Ecuador & 740 & 381 & 1.13 \\
\hline $\begin{array}{l}\text { Posadas, } \\
\text { Argentina }\end{array}$ & 1020 & 695 & 1.80 \\
\hline Total & 3230 & 1881 & 1.71 \\
\hline
\end{tabular}

Average and standard deviation values, and proportion of missing data for all numerical variables are shown in Additional File 2. Proportion of values for each factor level and proportion of missing data for all categorical variables are shown in Additional File 3. Water management and household characteristics directly affecting mosquito population abundance varied across the three wealth-index tertiles, with greater availability and use of mosquito control measures generally observed in households belonging to the highest wealth tertile (Table 2). Across study sites, arbovirus knowledge was 4.76 out of 6.00 , and standard deviation was 1.00 . Households of the lowest and middle wealth index tertiles were mostly found in neighborhoods that were considered of low socio-economic status prior to the study, while households of the highest wealth tertile were mostly found in neighborhoods considered of high socioeconomic status (Fig. 3). However, the reverse was not uncommon, with many households of the highest wealth tertile in neighborhoods of perceived low socio-economic status, and many households of the lowest and middle wealth tertiles in neighborhoods of perceived high socio-economic status. The majority of households belonging to the lowest wealth tertile were in Manta, Ecuador, whereas the majority of households belonging to the highest wealth tertile were in Ibagué, Colombia (Fig. 4). 
Table 2

Number of households (\% in each wealth index tertile in parentheses; $n=362$ ) included in the study by wealth index tertile and the reported answer ( $\varnothing$ : missing data) for each of 12 questions from the household questionnaire survey.

\begin{tabular}{|c|c|c|c|c|c|c|c|c|c|}
\hline \multirow{2}{*}{$\begin{array}{l}\text { Wealth Index tertile } \\
\text { Questionnaire answer }\end{array}$} & \multicolumn{3}{|c|}{ Lowest } & \multicolumn{3}{|c|}{ Middle } & \multicolumn{3}{|c|}{ Highest } \\
\hline & No & Yes & $\varnothing$ & No & Yes & $\varnothing$ & No & Yes & $\varnothing$ \\
\hline $\begin{array}{l}\text { Running water as main } \\
\text { source for drinking }\end{array}$ & $\begin{array}{l}134 \\
(37)\end{array}$ & $\begin{array}{l}227 \\
(63)\end{array}$ & $\begin{array}{l}1 \\
(0)\end{array}$ & $\begin{array}{l}108 \\
(30)\end{array}$ & $\begin{array}{l}254 \\
(70)\end{array}$ & $\begin{array}{l}0 \\
(0)\end{array}$ & $\begin{array}{l}84 \\
(23)\end{array}$ & $\begin{array}{l}278 \\
(77)\end{array}$ & $\begin{array}{l}0 \\
(0)\end{array}$ \\
\hline Problem obtaining water & $\begin{array}{l}229 \\
(63)\end{array}$ & $\begin{array}{l}131 \\
(36)\end{array}$ & $\begin{array}{l}2 \\
(1)\end{array}$ & $\begin{array}{l}266 \\
(73)\end{array}$ & $\begin{array}{l}94 \\
(26)\end{array}$ & $\begin{array}{l}2 \\
(1)\end{array}$ & $\begin{array}{l}298 \\
(82)\end{array}$ & $\begin{array}{l}63 \\
(17)\end{array}$ & $\begin{array}{l}1 \\
(0)\end{array}$ \\
\hline Storing water & $\begin{array}{l}274 \\
(76)\end{array}$ & $\begin{array}{l}86 \\
(24)\end{array}$ & $\begin{array}{l}2 \\
(1)\end{array}$ & $\begin{array}{l}219 \\
(60)\end{array}$ & $\begin{array}{l}143 \\
(40)\end{array}$ & $\begin{array}{l}0 \\
(0)\end{array}$ & $\begin{array}{l}166 \\
(46)\end{array}$ & $\begin{array}{l}196 \\
(54)\end{array}$ & $\begin{array}{l}0 \\
(0)\end{array}$ \\
\hline $\begin{array}{l}\text { Presence of large water } \\
\text { container }\end{array}$ & $\begin{array}{l}210 \\
(58)\end{array}$ & $\begin{array}{l}115 \\
(32)\end{array}$ & $\begin{array}{l}37 \\
(10)\end{array}$ & $\begin{array}{l}174 \\
(48)\end{array}$ & $\begin{array}{l}116 \\
(32)\end{array}$ & $\begin{array}{l}72 \\
(20)\end{array}$ & $\begin{array}{l}119 \\
(33)\end{array}$ & $\begin{array}{l}185 \\
(51)\end{array}$ & $\begin{array}{l}58 \\
(16)\end{array}$ \\
\hline Emptying containers & $\begin{array}{l}256 \\
(71)\end{array}$ & $\begin{array}{l}105 \\
(29)\end{array}$ & $\begin{array}{l}1 \\
(0)\end{array}$ & $\begin{array}{l}230 \\
(64)\end{array}$ & $\begin{array}{l}132 \\
(36)\end{array}$ & $\begin{array}{l}0 \\
(0)\end{array}$ & $\begin{array}{l}156 \\
(43)\end{array}$ & $\begin{array}{l}206 \\
(57)\end{array}$ & $\begin{array}{l}0 \\
(0)\end{array}$ \\
\hline Washing containers & $\begin{array}{l}253 \\
(70)\end{array}$ & $\begin{array}{l}108 \\
(30)\end{array}$ & $\begin{array}{l}1 \\
(0)\end{array}$ & $\begin{array}{l}215 \\
(59)\end{array}$ & $\begin{array}{l}147 \\
(41)\end{array}$ & $\begin{array}{l}0 \\
(0)\end{array}$ & $\begin{array}{l}140 \\
(39)\end{array}$ & $\begin{array}{l}222 \\
(61)\end{array}$ & $\begin{array}{l}0 \\
(0)\end{array}$ \\
\hline $\begin{array}{l}\text { Presence of vegetation in } \\
\text { pots }\end{array}$ & $\begin{array}{l}259 \\
(72)\end{array}$ & $\begin{array}{l}86 \\
(24)\end{array}$ & $\begin{array}{l}17 \\
(5)\end{array}$ & $\begin{array}{l}236 \\
(65)\end{array}$ & $\begin{array}{l}120 \\
(33)\end{array}$ & $\begin{array}{l}6 \\
(2)\end{array}$ & $\begin{array}{l}263 \\
(73)\end{array}$ & $\begin{array}{l}98 \\
(27)\end{array}$ & $\begin{array}{l}1 \\
(0)\end{array}$ \\
\hline Using window screens & $\begin{array}{l}320 \\
(88)\end{array}$ & $\begin{array}{l}41 \\
(11)\end{array}$ & $\begin{array}{l}1 \\
(0)\end{array}$ & $\begin{array}{l}330 \\
(91)\end{array}$ & $\begin{array}{l}32 \\
(9)\end{array}$ & $\begin{array}{l}0 \\
(0)\end{array}$ & $\begin{array}{l}281 \\
(78)\end{array}$ & $\begin{array}{l}81 \\
(22)\end{array}$ & $\begin{array}{l}0 \\
(0)\end{array}$ \\
\hline $\begin{array}{l}\text { Presence of points of entry } \\
\text { for mosquitoes }\end{array}$ & $\begin{array}{l}219 \\
(60)\end{array}$ & $\begin{array}{l}137 \\
(38)\end{array}$ & $\begin{array}{l}6 \\
(2)\end{array}$ & $\begin{array}{l}277 \\
(77)\end{array}$ & $\begin{array}{l}85 \\
(23)\end{array}$ & $\begin{array}{l}0 \\
(0)\end{array}$ & $\begin{array}{l}290 \\
(80)\end{array}$ & $\begin{array}{l}69 \\
(19)\end{array}$ & $\begin{array}{l}3 \\
(1)\end{array}$ \\
\hline Permanent floor materials & $6(2)$ & $\begin{array}{l}354 \\
(98)\end{array}$ & $\begin{array}{l}2 \\
(1)\end{array}$ & $2(1)$ & $\begin{array}{l}360 \\
(99)\end{array}$ & $\begin{array}{l}0 \\
(0)\end{array}$ & $0(0)$ & $\begin{array}{l}362 \\
(100)\end{array}$ & $\begin{array}{l}0 \\
(0)\end{array}$ \\
\hline Permanent roof materials & $\begin{array}{l}21 \\
(6)\end{array}$ & $\begin{array}{l}338 \\
(93)\end{array}$ & $\begin{array}{l}3 \\
(1)\end{array}$ & $9(2)$ & $\begin{array}{l}353 \\
(98)\end{array}$ & $\begin{array}{l}0 \\
(0)\end{array}$ & $2(1)$ & $\begin{array}{l}359 \\
(99)\end{array}$ & $\begin{array}{l}1 \\
(0)\end{array}$ \\
\hline Permanent wall materials & $\begin{array}{l}14 \\
(4)\end{array}$ & $\begin{array}{l}346 \\
(96)\end{array}$ & $\begin{array}{l}2 \\
(1)\end{array}$ & $3(1)$ & $\begin{array}{l}359 \\
(99)\end{array}$ & $\begin{array}{l}0 \\
(0)\end{array}$ & $2(1)$ & $\begin{array}{l}359 \\
(99)\end{array}$ & $\begin{array}{l}1 \\
(0)\end{array}$ \\
\hline Presence of breeding sites & $\begin{array}{l}255 \\
(70)\end{array}$ & $\begin{array}{l}60 \\
(17)\end{array}$ & $\begin{array}{l}47 \\
(13)\end{array}$ & $\begin{array}{l}271 \\
(75)\end{array}$ & $\begin{array}{l}60 \\
(17)\end{array}$ & $\begin{array}{l}31 \\
(9)\end{array}$ & $\begin{array}{l}291 \\
(80)\end{array}$ & $\begin{array}{l}53 \\
(15)\end{array}$ & $\begin{array}{l}18 \\
(5)\end{array}$ \\
\hline
\end{tabular}

\section{Analyses of household wealth and neighborhood socio- economic profile}

We found a marginally significant association $(P=0.048)$ of the interaction between perceived neighborhood socio-economic status and household wealth index on household female Aedes spp. mosquito abundance. While no significant association was found for households on the lowest and middle wealth tertiles, household female Aedes spp. mosquito abundance was higher for households of 
the highest wealth index tertile situated in neighborhoods of perceived low socio-economic status, compared to those situated in neighborhoods of perceived high socio-economic status. When examining this association using our standardized measure of neighborhood poverty, we found a highly significant association $(P<0.001)$ of the interaction between neighborhood poverty and household wealth index on household female Aedes spp. mosquito abundance. Households of the highest wealth index tertile situated in neighborhoods with a low proportion of lowest wealth households had the lowest household female Aedes spp. mosquito abundance. Interestingly, this trend was reversed in neighborhoods with a high proportion of lowest wealth households (Fig. 5).

\section{Analyses of household and occupants characteristics}

All results of simple regression analyses can be found in Additional File 2 and Additional File 3 . Using the entire dataset across study sites, the final model contained 11 predictors, nine of which had an IRR that was significantly different from 1 (Table 3). Number of occupants in the household, number of years living in the household, and using bed nets had an IRR value between 1.05 and 1.35, and presence of points of entry into the household for mosquitoes and presence of other/decorative vegetation, had a large IRR of more than 1.5. Arbovirus knowledge, the highest wealth index tertile, emptying containers, and presence of herbs, had an IRR value between 0.75 and 0.95 (Table 3). Marginal and conditional $R^{2}$ of the final model were 0.1 and 0.6 , respectively. 
Table 3

Mixed-effects regression incidence rate ratio (IRR) values, the two boundaries of the $95 \%$ confidence interval (IRR $2.5 \%$ and $97.5 \% \mathrm{Cl}$ ), and the $P$ value, for each predictor included in the final model of household female Aedes spp. mosquito abundance for the entire dataset across study sites.

\begin{tabular}{|c|c|c|c|c|c|}
\hline Predictor & Level & IRR & $\begin{array}{l}\text { IRR 2.5\% } \\
\mathrm{Cl}\end{array}$ & $\begin{array}{l}\text { IRR } 97.5 \% \\
\mathrm{Cl}\end{array}$ & $P$ \\
\hline Number of occupants & & 1.08 & 1.01 & 1.14 & 0.012 \\
\hline Number of occupants who study & & 1.01 & 0.95 & 1.08 & 0.660 \\
\hline Years spent living in household & & 1.20 & 1.11 & 1.29 & $\dot{0} 001$ \\
\hline Arbovirus knowledge & & 0.94 & 0.89 & 1.00 & 0.042 \\
\hline \multirow[t]{3}{*}{ Wealth index } & Lowest & \multicolumn{4}{|c|}{ Reference } \\
\hline & Middle & 0.89 & 0.76 & 1.05 & 0.149 \\
\hline & Highest & 0.78 & 0.66 & 0.92 & 0.004 \\
\hline \multirow[t]{2}{*}{ Using bed net } & No & \multicolumn{4}{|c|}{ Reference } \\
\hline & Yes & 1.31 & 1.07 & 1.59 & 0.007 \\
\hline \multirow[t]{2}{*}{ Emptying containers } & No & \multicolumn{4}{|c|}{ Reference } \\
\hline & Yes & 0.79 & 0.67 & 0.92 & 0.003 \\
\hline \multirow{2}{*}{$\begin{array}{l}\text { Presence of points of entry for } \\
\text { mosquitoes }\end{array}$} & No & \multicolumn{4}{|c|}{ Reference } \\
\hline & Yes & 1.51 & 1.30 & 1.76 & ¿. 001 \\
\hline \multirow[t]{2}{*}{ Presence of green areas around house } & No & \multicolumn{4}{|c|}{ Reference } \\
\hline & Yes & 1.10 & 0.96 & 1.26 & 0.152 \\
\hline \multirow[t]{2}{*}{ Presence of herbs } & No & \multicolumn{4}{|c|}{ Reference } \\
\hline & Yes & 0.86 & 0.75 & 0.99 & 0.034 \\
\hline \multirow[t]{2}{*}{ Presence of other/decorative vegetation } & No & \multicolumn{4}{|c|}{ Reference } \\
\hline & Yes & 1.52 & 1.22 & 1.88 & $\hat{L}_{0.001}$ \\
\hline
\end{tabular}

Using the dataset from Ibagué, Colombia, our final model contained 14 predictors, 13 of which had an IRR that was significantly different from 1 (Table 4). Number of total occupants and number of students, number of floors in the household, and presence of green areas and absence of water bodies near the household all had an IRR between 1.10 and 1.50. Presence of other/decorative vegetation had a large IRR of 1.59, and waste collection method, whether it was in a location outside the household or collected by municipal/private agency compared to inside the property, both had an exceptionally large IRR of more than 8.00. Number of family cores, distance to nearest household, and arbovirus knowledge, the highest 
wealth index tertile, using insecticide, and other means of protection against mosquitoes (mostly electric rackets, fans, and insecticide tablets) had an IRR between 0.65 and 0.90 (Table 4). Marginal and conditional $\mathrm{R}^{2}$ of the final model were 0.2 and 0.7 , respectively. 
Table 4

Mixed-effects regression incidence rate ratio (IRR) values, the two boundaries of the $95 \%$ confidence interval (IRR $2.5 \%$ and $97.5 \% \mathrm{Cl}$ ), and the $P$ value, for each predictor included in the final model of household female Aedes spp. mosquito abundance for the dataset from Ibagué, Colombia.

\begin{tabular}{|c|c|c|c|c|c|}
\hline Predictor & Level & IRR & $\begin{array}{l}\text { IRR } \\
2.5 \% \\
\mathrm{Cl}\end{array}$ & $\begin{array}{l}\text { IRR } \\
97.5 \% \\
\mathrm{Cl}\end{array}$ & $P$ \\
\hline Number of occupants & & 1.16 & 1.05 & 1.28 & 0.002 \\
\hline Number of occupants who study & & 1.13 & 1.02 & 1.25 & 0.017 \\
\hline Number of floors & & 1.23 & 1.11 & 1.34 & ¿.001 \\
\hline Number of family cores & & 0.78 & 0.70 & 0.87 & <. 001 \\
\hline Distance to nearest household & & 0.89 & 0.80 & 0.98 & 0.019 \\
\hline Arbovirus knowledge & & 0.87 & 0.81 & 0.94 & $\hat{0}_{0.001}$ \\
\hline \multirow[t]{3}{*}{ Wealth index } & Lowest & \multicolumn{4}{|c|}{ Reference } \\
\hline & Middle & 0.87 & 0.69 & 1.11 & 0.257 \\
\hline & Highest & 0.65 & 0.51 & 0.84 & 0.001 \\
\hline \multirow[t]{2}{*}{ Insecticide use } & No & \multicolumn{4}{|c|}{ Reference } \\
\hline & Yes & 0.83 & 0.71 & 0.98 & 0.023 \\
\hline \multirow[t]{2}{*}{ Killing insects } & No & \multicolumn{4}{|c|}{ Reference } \\
\hline & Yes & 0.82 & 0.62 & 1.06 & 0.129 \\
\hline \multirow{2}{*}{$\begin{array}{l}\text { Use of other means of protection } \\
\text { against mosquitoes }\end{array}$} & No & \multicolumn{4}{|c|}{ Reference } \\
\hline & Yes & 0.68 & 0.53 & 0.85 & 0.001 \\
\hline \multirow{2}{*}{$\begin{array}{l}\text { Presence of green areas around } \\
\text { household }\end{array}$} & No & \multicolumn{4}{|c|}{ Reference } \\
\hline & Yes & 1.26 & 1.04 & 1.52 & 0.018 \\
\hline \multirow{2}{*}{$\begin{array}{l}\text { Presence of water bodies near } \\
\text { household }\end{array}$} & Yes & \multicolumn{4}{|c|}{ Reference } \\
\hline & No & 1.47 & 1.08 & 1.97 & 0.011 \\
\hline \multirow{2}{*}{$\begin{array}{l}\text { Presence of other/decorative } \\
\text { vegetation }\end{array}$} & No & \multicolumn{4}{|c|}{ Reference } \\
\hline & Yes & 1.59 & 1.26 & 2.00 & $\begin{array}{l}< \\
0.001\end{array}$ \\
\hline \multirow[t]{2}{*}{ Waste collection method } & Inside property & \multicolumn{4}{|c|}{ Reference } \\
\hline & Outside property & 9.63 & 2.03 & 176.58 & 0.026 \\
\hline
\end{tabular}




\begin{tabular}{|c|c|c|c|c|c|}
\hline Predictor & Level & IRR & $\begin{array}{l}\text { IRR } \\
2.5 \% \\
\mathrm{Cl}\end{array}$ & $\begin{array}{l}\text { IRR } \\
97.5 \% \\
\mathrm{Cl}\end{array}$ & $P$ \\
\hline & $\begin{array}{l}\text { Private or municipal } \\
\text { collection }\end{array}$ & 8.91 & 1.93 & 163.28 & 0.030 \\
\hline
\end{tabular}

Using the dataset from Manta, Ecuador, our final model contained 11 predictors, five of which had an IRR that was significantly different from 1 (Table 5). Humidity had an IRR value of 1.39 , and problem obtaining water and using insecticide had a large IRR of more than 2.00. Presence of container in the yard had an IRR value of 0.69 , and the 'weekly' level of frequency of garbage collection had a small IRR value of 0.36 (Table 5). Marginal and conditional $R^{2}$ of the final model were 0.3 and 0.5 , respectively. 
Table 5

Mixed-effects regression incidence rate ratio (IRR) values, the two boundaries of the $95 \%$ confidence interval (IRR $2.5 \%$ and $97.5 \% \mathrm{Cl}$ ), and the $P$ value, for each predictor included in the final model of household female Aedes spp. mosquito abundance for the dataset from Manta, Ecuador.

\begin{tabular}{|c|c|c|c|c|c|}
\hline Predictor & Level & IRR & IRR $2.5 \% \mathrm{Cl}$ & IRR $97.5 \%$ Cl & $P$ \\
\hline Humidity & & 1.39 & 1.10 & 1.76 & 0.005 \\
\hline Arbovirus knowledge & & 1.11 & 0.89 & 1.39 & 0.364 \\
\hline \multirow[t]{2}{*}{ Presence of container in the yard } & No & \multicolumn{4}{|c|}{ Reference } \\
\hline & Yes & 0.69 & 0.50 & 0.96 & 0.025 \\
\hline \multirow[t]{2}{*}{ Presence of water tank } & No & \multicolumn{4}{|c|}{ Reference } \\
\hline & Yes & 1.04 & 0.73 & 1.47 & 0.839 \\
\hline \multirow[t]{2}{*}{ Problem obtaining water } & No & \multicolumn{4}{|c|}{ Reference } \\
\hline & Yes & 2.07 & 1.41 & 3.05 & $<0.001$ \\
\hline \multirow[t]{2}{*}{ Store water to wash } & No & \multicolumn{4}{|c|}{ Reference } \\
\hline & Yes & 1.44 & 0.91 & 2.26 & 0.115 \\
\hline \multirow[t]{2}{*}{ Store water to cook } & No & \multicolumn{4}{|c|}{ Reference } \\
\hline & Yes & 0.95 & 0.68 & 1.31 & 0.733 \\
\hline \multirow[t]{2}{*}{ Insecticide use } & No & \multicolumn{4}{|c|}{ Reference } \\
\hline & Yes & 2.05 & 1.47 & 2.85 & $<0.001$ \\
\hline \multirow[t]{2}{*}{ Washing containers } & No & \multicolumn{4}{|c|}{ Reference } \\
\hline & Yes & 1.11 & 0.53 & 2.29 & 0.782 \\
\hline \multirow[t]{2}{*}{ Killing insects } & No & \multicolumn{4}{|c|}{ Reference } \\
\hline & Yes & 0.79 & 0.45 & 1.35 & 0.386 \\
\hline \multirow[t]{4}{*}{ Frequency of garbage collection } & Every other day & \multicolumn{4}{|c|}{ Reference } \\
\hline & Daily & 1.59 & 0.98 & 2.62 & 0.064 \\
\hline & Unpredictable & 0.95 & 0.40 & 2.09 & 0.894 \\
\hline & Weekly & 0.36 & 0.12 & 0.92 & 0.041 \\
\hline
\end{tabular}

Using the dataset from Posadas, Argentina, our final model contained 15 predictors, five of which had an IRR that was significantly different from 1 (Table 6). Number of family cores had an IRR value of 1.31, and the 'unpredictable' level of frequency of obtaining water, storing water, and presence of points of entry for mosquitoes into the household had a large IRR of 1.70 and more. The 'property' level of type of lease, and using other means of protection against mosquitoes (mostly using ventilators and insecticide 
tablets) had a small IRR value of less than 0.55 (Table 6 ). Marginal and conditional $\mathrm{R}^{2}$ of the final model were 0.4 and 0.5 , respectively. 
Table 6

Mixed-effects regression incidence rate ratio (IRR) values, the two boundaries of the $95 \%$ confidence interval (IRR $2.5 \%$ and $97.5 \% \mathrm{Cl}$ ), and the $P$ value, for each predictor included in the final model of household female Aedes spp. mosquito abundance for the dataset from Posadas, Argentina.

\begin{tabular}{|c|c|c|c|c|c|}
\hline Predictor & Level & IRR & $\begin{array}{l}\text { IRR } 2.5 \% \\
\mathrm{Cl}\end{array}$ & $\begin{array}{l}\text { IRR } 97.5 \% \\
\mathrm{Cl}\end{array}$ & $P$ \\
\hline Number of occupants & & 1.25 & 0.98 & 1.58 & 0.063 \\
\hline Years spent living in household & & 0.81 & 0.55 & 1.14 & 0.260 \\
\hline Number of floors & & 0.76 & 0.53 & 1.05 & 0.110 \\
\hline Number of family cores & & 1.31 & 1.08 & 1.59 & 0.005 \\
\hline Distance to nearest household & & 1.08 & 0.92 & 1.27 & 0.352 \\
\hline \multirow[t]{3}{*}{ Type of lease } & Rental & \multicolumn{4}{|c|}{ Reference } \\
\hline & Family & 2.68 & 0.80 & 9.38 & 0.110 \\
\hline & Property & 0.42 & 0.20 & 0.91 & 0.023 \\
\hline \multirow[t]{4}{*}{ Frequency of obtaining water } & $\begin{array}{l}\text { Every other } \\
\text { day }\end{array}$ & \multicolumn{4}{|c|}{ Reference } \\
\hline & Daily & 1.45 & 0.82 & 2.73 & 0.212 \\
\hline & Unpredictable & 2.96 & 1.70 & 5.25 & $\hat{0.001}$ \\
\hline & Weekly & 0.89 & 0.26 & 2.90 & 0.851 \\
\hline \multirow[t]{2}{*}{ Problem obtaining water } & No & \multicolumn{4}{|c|}{ Reference } \\
\hline & Yes & 0.77 & 0.47 & 1.30 & 0.304 \\
\hline \multirow[t]{2}{*}{ Storing water } & No & \multicolumn{4}{|c|}{ Reference } \\
\hline & Yes & 1.70 & 1.02 & 2.88 & 0.043 \\
\hline \multirow[t]{2}{*}{ Using bed nets } & No & \multicolumn{4}{|c|}{ Reference } \\
\hline & Yes & 0.73 & 0.41 & 1.30 & 0.283 \\
\hline \multirow[t]{2}{*}{ Using window screens } & No & \multicolumn{4}{|c|}{ Reference } \\
\hline & Yes & 1.79 & 0.77 & 3.81 & 0.146 \\
\hline \multirow{2}{*}{$\begin{array}{l}\text { Other means of protection against } \\
\text { mosquitoes }\end{array}$} & No & \multicolumn{4}{|c|}{ Reference } \\
\hline & Yes & 0.52 & 0.27 & 0.93 & 0.031 \\
\hline \multirow{2}{*}{$\begin{array}{l}\text { Points of entry for mosquitoes into } \\
\text { household }\end{array}$} & No & \multicolumn{4}{|c|}{ Reference } \\
\hline & Yes & 2.70 & 1.05 & 6.67 & 0.026 \\
\hline
\end{tabular}




\begin{tabular}{|llllll|}
\hline Predictor & Level & IRR & $\begin{array}{c}\text { IRR 2.5\% } \\
\text { Cl }\end{array}$ & $\begin{array}{l}\text { IRR 97.5\% } \\
\text { Cl }\end{array}$ & $P$ \\
\hline Presence of vegetation inside household & No & Reference & & \\
\cline { 2 - 6 } & Yes & 1.41 & 0.75 & 2.90 & 0.314 \\
\hline Presence of breeding sites & No & Reference & & \\
\cline { 2 - 6 } & Yes & 1.55 & 0.79 & 3.02 & 0.192 \\
\hline
\end{tabular}

\section{Discussion}

Our study of arbovirus vector dynamics in three Latin American countries, chosen to reflect different ecoepidemiological settings, identified substantial variations in household-level Aedes mosquito density, both within and among study sites, and over time. Importantly, we identified several relevant determinants of vector density across study sites, while other factors were more important in certain local contexts. These findings can help to inform disease mitigation strategies by identifying modifiable risk factors that can be targeted for disease prevention and control, recognizing that local tailoring of solutions will be required.

We found considerable socio-economic differences across the three study sites when we applied a common measure of asset-based household wealth. Interestingly, we identified a complex relationship between household-level wealth and neighborhood-level socio-economic profile in terms of their interactive effect on Aedes density, wherein the highest arbovirus vector density was observed in lowest wealth households from neighborhoods of high socio-economic profile. This suggest that residents of poor households may differ in their exposure to Aedes mosquitoes compared with residents of wealthier households in the same neighborhood. In wealthier neighborhoods (i.e. low proportion of lowest wealth households), Aedes density decreased as household wealth increased, while in poorer neighborhoods (i.e. high proportion of lowest wealth households), Aedes density increased with increasing household wealth. In contrast to the highest Aedes density being observed in lowest wealth households situated in wealthier neighborhoods, lowest wealth households in poorer neighborhoods displayed the lowest Aedes density. A combination of factors could explain these results: in wealthier neighborhoods, lower household wealth, possibly accompanied with lower arbovirus knowledge, poorer household structure and weaker water and waste management $[24,26,27,39-41]$, are potentially accompanied with unequal mosquito control by municipal authorities, which is usually targeted to neighborhoods with higher disease incidence [42]. Wealthier households may also contribute to Aedes breeding, potentially through landscape and vegetation elements in and around the household, such as managed water containers for decorative plants and green areas around the household [28]. This could potentially support our results suggesting larger Aedes density in wealthiest households, compared to lowest wealth households, in poorer neighborhoods. These effects should be investigated further to discriminate the main determinants of Aedes breeding and identify appropriate control methods. Nonetheless, these results illustrate the 
importance of considering equity at the household level when targeting mosquito control interventions, which are usually delivered at the neighborhood level.

Our study results indicate that meteorological, climatic and socio-economic variation have all likely contributed to shaping conditions conducive to Aedes density in our study across the three sites. This is reflected by the six-fold increase in $\mathrm{R}^{2}$ when accounting for temporal and spatial random-effects (i.e. conditional $\mathrm{R}^{2}$ compared to marginal $\mathrm{R}^{2}$ ) parameters in our multivariable regression analyses across study sites. In addition to these spatial and temporal effects, other fine-scale processes are likely to have played a role in shaping individual household responses to dealing with Aedes mosquitoes. This is reflected by the differences we observed in the predictive power of variables that we investigated among and across the three study sites. Analyses of households of Ibagué, Colombia, suggested a major role of variables associated with household occupants' characteristics, such as crowding, wealth index, and respondent arbovirus knowledge, but also indoor and outdoor household components. Number of occupants in a household, number of floors, and distance between households all affected the observed densities of Aedes mosquitoes, with a higher degree of crowding associated with higher Aedes density. Indeed, an increase in unplanned urbanization, which is typically the result of a rapid increases in human population density, is associated with the creation of new suitable habitats for Aedes mosquitoes [17, 25, 43]. We found that wealthier households where occupants displayed higher knowledge of arboviruses were associated with lower Aedes density. Household wealth is widely known to affect mosquito vector density, potentially through better access to mosquito control methods [22, 26, 39], and the effect of knowledge about mosquito vectors and arboviruses on household mosquito vector density and arboviral disease risk has also been the subject of many studies [27, 44,45]. We also found major effects of presence of decorative vegetation and landscape elements around the household. Presence of decorative vegetation and green areas in and around the household, and absence of water bodies near the household, all led to higher Aedes densities. These effects can be explained by the ecology of Aedes mosquitoes, which frequently use discarded containers filled with exposed and shady standing water as breeding sites, and use water bodies less frequently, especially those with flowing water and/or situated more than 25 meters away from the household [46]. In a study in the United States, managed container habitats in higher wealth neighborhoods, such as those used for decorative plants, and vegetation around households with high abandonment were both associated with higher Aedes density [28].

In contrast, analyses of households in Manta, Ecuador, suggested a major role of variables associated with water and waste management, and humidity. Presence of a large water container in or around the household was significantly associated with lower Aedes density. On the other hand, humidity, difficulty in obtaining water and weekly waste collection frequency were all significantly associated with larger Aedes density. Efficient water management, such as a storage dedicated container [40, 41, 47], and frequent waste management, which prevents formation of mosquito breeding sites [24, 48], are typically associated with better mosquito control.

Analyses of households in Posadas, Argentina, and across the three sites, suggested a major role of a mixture of these effects. In Posadas, households that were owned and that did not display structural 
points of entry for mosquitoes, displayed lower Aedes density, while unpredictable access to water by occupants and storing water were associated to higher Aedes density. In analyses across the three study sites, fewer household occupants, higher knowledge of arboviruses by occupants, living fewer years in the household, wealthier households, and absence of structural points of entry for mosquitoes into the household, were all associated with lower Aedes density. Also, across study sites, reporting that water containers were regularly emptied by occupants, and absence of decorative vegetation, led to lower Aedes density. Interestingly, using pesticides in Manta, Ecuador, and using bed nets across study sites showed a positive association with Aedes density. These results may either reflect that use of such mosquito control methods is driven by need, e.g. when mosquitoes are present in high numbers, or that their effect on diurnal mosquitoes is limited. Altogether, our results point to modifiable risk factors related to water and waste management that should be the target of future interventions. These interventions should be prioritized in lower wealth households, regardless of the neighborhood's overall socioeconomic status, and include an educational component to raise awareness of risks associated with Aedes mosquito presence and potential control methods.

Several logistical challenges arose during our study, which led to a delay in the start of the study timeline for two of our study sites. As a result, the study timeline differed across the three sites and the entire timeline for the study lasted 21 months, instead of 12 months. However, we achieved some temporal overlap in study timeline among the three sites for comparability. In addition, two study sites did not have the expected total number of households per neighborhood for high socio-economic areas. For this reason, we sampled households in more than two neighborhoods of high socio-economic status in these study sites. This could have led to a difference in spatial resolution between neighborhoods of high versus low socio-economic status. However, all neighborhoods were located within close proximity to each other. Our regression analyses incorporated random effects for the month of sampling, nested in sampled neighborhood, nested in study site, therefore results of these analyses are unlikely to have been affected by potential temporal and spatial biases.

\section{Conclusions}

Our study identified key variables affecting Aedes mosquito density across three study sites reflecting different eco-epidemiological settings in the Latin America and Caribbean region. We also shed some light on the complex interplay that exists between neighborhood poverty level and household SES in our study's neighborhoods. Our results could help to elucidate some of the complexity in the relationship between meteorological, climatic, and socio-economic factors and specific household characteristics that contribute to Aedes mosquito vector density, and hence arbovirus risk, in the Latin America and Caribbean region.

\section{Declarations}

\section{Ethics approval and consent to participate}


Ethics approval was obtained from the University of Ottawa Science and Health Sciences Research Ethics Board (certificate H-10-19-4970), the University Health Network Research Ethics Board (certificate 175782), the Committee on Research Ethics of the Universidad de los Andes (certificate 839-2018), the Institutional Review Board of the Universidad San Francisco de Quito (certificate 2016-173IN) and the Provincial Investigation Ethics Committee of the Public Health Ministry in Misiones, Argentina.

\section{Consent for publication}

Not applicable.

\section{Availability of data and materials}

All data generated or analysed during this study are included in this published article and its supplementary information files.

\section{Competing interests}

The authors declare that they have no competing interests.

\section{Funding}

This research is part of an international research project entitled "Assessing ZIKV transmission dynamics and mitigation strategies: A multidisciplinary approach" funded by the Canadian Institutes of Health Research (CIHR) and the International Development Research Centre (IDRC) Canada-Latin America and Caribbean Zika Virus Research Program (CIHR grant number ZV3-149784 and IDRC Project Number 108409-001).

\section{Authors' contributions}

$B S, V C, C G, M E, J W, M M$ and MAK were involved in the conception of the study; BT, BS, VC, CG, MM and MAK developed the study design; BT, DB, CC, MCCF, NG, SL, KL, MIO, PP, SDV and FZ conducted the acquisition and analysis of data; BT, BS, VC, CG, MM and MAK interpreted the data; BT and MAK drafted or substantively revised the manuscript.

\section{Acknowledgments}

Research was conducted by the team entitled RADAM-LAC 'Research on Arbovirus Dynamics and Mitigation-Latin America and Canada', with field study sites in Colombia, Ecuador and Argentina. We thank all field and laboratory staff from each study site for their valuable work that made this project possible. In particular, we thank Santiago Valenzuela, Mabel Sánchez, Milton Espinosa, ULEAM students and ULEAM professors for assisting in fieldwork and data collection in Manta, Ecuador.

\section{References}


1. Gubler DJ. The global threat of emergent/re-emergent vector-borne diseases. In: Atkinson PW, editor. Vector biology, ecology and control. Dordrecht: Springer Netherlands; 2010. pp. 39-62. doi:10.1007/978-90-481-2458-9_4.

2. Morens DM, Fauci AS. Emerging infectious diseases: threats to human health and global stability. PLoS Pathog. 2013;9:e1003467.

3. Dick GWA, Kitchen SF, Haddow AJ. Zika virus. I. Isolations and serological specificity. Trans R Soc Trop Med Hyg. 1952;46:509-20.

4. Delatorre E, Fernández J, Bello G. Investigating the role of Easter Island in migration of Zika virus from South Pacific to Americas. Emerg Infect Dis. 2018;24:2119-21.

5. Krauer F, Riesen M, Reveiz L, Oladapo OT, Martínez-Vega R, Porgo TV, et al. Zika Virus Infection as a Cause of Congenital Brain Abnormalities and Guillain-Barré Syndrome: Systematic Review. PLoS Med. 2017;14:e1002203.

6. Murray NEA, Quam MB, Wilder-Smith A. Epidemiology of dengue: past, present and future prospects. Clin Epidemiol. 2013;5:299-309.

7. Yactayo S, Staples JE, Millot V, Cibrelus L, Ramon-Pardo P. Epidemiology of Chikungunya in the Americas. J Infect Dis. 2016;214(suppl 5):441-5.

8. Powell JR, Tabachnick WJ, Powell JR, Tabachnick WJ. History of domestication and spread of Aedes aegypti - A Review. Memórias do Instituto Oswaldo Cruz. 2013;108:11-7.

9. Enserink M. A mosquito goes global. Science. 2008;320:864-6.

10. Wagman J, Grieco JP, King R, Briceño I, Bautista K, Polanco J, et al. First record and demonstration of a southward expansion of Aedes albopictus into Orange Walk Town, Belize, Central America. J Am Mosq Control Assoc. 2013;29:380-2.

11. Kraemer MUG, Reiner RC, Brady OJ, Messina JP, Gilbert M, Pigott DM, et al. Past and future spread of the arbovirus vectors Aedes aegypti and Aedes albopictus. Nat Microbiol. 2019;4:854-63.

12. Miller MJ, Loaiza JR. Geographic expansion of the invasive mosquito Aedes albopictus across Panama-implications for control of dengue and Chikungunya viruses. PLoS Negl Trop Dis. 2015;9:e0003383.

13. Muñoz ÁG, Thomson MC, Goddard LM, Aldighieri S. The Latin American and Caribbean climate landscape for ZIKV transmission. 2016. doi:10.7916/D8X34XHV.

14. Lega J, Brown HE, Barrera R. Aedes aegypti (Diptera: Culicidae) abundance model improved with relative humidity and precipitation-driven egg hatching. J Med Entomol. 2017;54:1375-84.

15. Jones R, Kulkarni MA, Davidson TMV, Research Team RADAM-LAC, Talbot B. Arbovirus vectors of epidemiological concern in the Americas: A scoping review of entomological studies on Zika, dengue and chikungunya virus vectors. PLoS ONE. 2020;15:e0220753.

16. Elmqvist T, Fragkias M, Goodness J, Güneralp B, Marcotullio PJ, McDonald RI et al, editors. Urbanization, biodiversity and ecosystem services: challenges and opportunities. Dordrecht: Springer Netherlands; 2013. doi:10.1007/978-94-007-7088-1. 
17. Li Y, Kamara F, Zhou G, Puthiyakunnon S, Li C, Liu Y, et al. Urbanization increases Aedes albopictus larval habitats and accelerates mosquito development and survivorship. PLoS Negl Trop Dis. 2014;8:e3301.

18. Kjellstrom T, Friel S, Dixon J, Corvalan C, Rehfuess E, Campbell-Lendrum D, et al. Urban environmental health hazards and health equity. J Urban Health. 2007;84:86-97.

19. Eisenstein M. Disease. Poverty and pathogens. Nature. 2016;531:61-3.

20. Murray M, Edwards MA, Abercrombie B. St. Clair CC. Poor health is associated with use of anthropogenic resources in an urban carnivore. Proc R Soc B. 2015;282:20150009.

21. Galea S. Urban built environment and depression: a multilevel analysis. Journal of Epidemiology Community Health. 2005;59:822-7.

22. Donnelly MAP, Kluh S, Snyder RE, Barker CM. Quantifying sociodemographic heterogeneities in the distribution of Aedes aegypti among California households. PLoS Negl Trop Dis. 2020;14:e0008408.

23. Whiteman A, Loaiza JR, Yee DA, Poh KC, Watkins AS, Lucas KJ, et al. Do socioeconomic factors drive Aedes mosquito vectors and their arboviral diseases? A systematic review of dengue, chikungunya, yellow fever, and Zika Virus. One Health. 2020;11:100188.

24. Barrera R, Navarro JC, Mora JD, Domínguez D, González J. Public service deficiencies and Aedes aegypti breeding sites in Venezuela. Bull Pan Am Health Organ. 1995;29:193-205.

25. Fuentes-Vallejo M, Higuera-Mendieta DR, García-Betancourt T, Alcalá-Espinosa LA, García-Sánchez D, Munévar-Cagigas DA, et al. Territorial analysis of Aedes aegypti distribution in two Colombian cities: a chorematic and ecosystem approach. Cad Saude Publica. 2015;31:517-30.

26. Whiteman A, Gomez C, Rovira J, Chen G, McMillan WO, Loaiza J. Aedes mosquito infestation in socioeconomically contrasting neighborhoods of Panama City. EcoHealth. 2019;16:210-21.

27. Dowling Z, Armbruster P, LaDeau SL, DeCotiis M, Mottley J, Leisnham PT. Linking mosquito infestation to resident socioeconomic status, knowledge, and source reduction practices in suburban Washington, DC. EcoHealth. 2013;10:36-47.

28. Little E, Biehler D, Leisnham PT, Jordan R, Wilson S, LaDeau SL. Socio-ecological mechanisms supporting high densities of Aedes albopictus (Diptera: Culicidae) in Baltimore, MD. J Med Entomol. 2017;54:1183-92.

29. Costa EAP, de A, Santos, EM de M, Correia, JC, Albuquerque CMR de. Impact of small variations in temperature and humidity on the reproductive activity and survival of Aedes aegypti (Diptera, Culicidae). Rev Bras entomol. 2010;54:488-93.

30. da Cruz Ferreira DA, Degener CM, de Almeida Marques-Toledo C, Bendati MM, Fetzer LO, Teixeira CP, et al. Meteorological variables and mosquito monitoring are good predictors for infestation trends of Aedes aegypti, the vector of dengue, chikungunya and Zika. Parasit Vectors. 2017;10:78.

31. Codeço CT, Honório NA, Ríos-Velásquez CM, Santos M da CA dos, Mattos de Luz IV SB, et al. Seasonal dynamics of Aedes aegypti (Diptera: Culicidae) in the northernmost state of Brazil: a likely port-of-entry for dengue virus 4. Mem Inst Oswaldo Cruz. 2009;104:614-20. 
32. Carbajo $A E$, Vezzani $D$. Waiting for chikungunya fever in Argentina: spatio-temporal risk maps. Mem Inst Oswaldo Cruz. 2015;110:259-62.

33. Harbach RE, Knight KL. Taxonomists' glossary of mosquito anatomy. Marton: Plexus; 1980.

34. Vyas S, Kumaranayake L. Constructing socio-economic status indices: how to use principal components analysis. Health Policy Plann. 2006;21:459-68.

35. Searle SR, Speed FM, Milliken GA. Population marginal means in the linear model: an alternative to least squares means. The American Statistician. 1980;34:216-21.

36. Bates D, Mächler M, Bolker B, Walker S. Fitting linear mixed-effects models Using Ime4. J Stat Soft. 2015;67. doi:10.18637/jss.v067.i01.

37. Fox J, Weisberg S. An R companion to applied regression. 2nd edition. Thousand Oaks, CA, USA: SAGE Publishing; 2011.

38. Barton K. MuMIn: multi-model inference. Krakow. Poland: Institute of Nature Conservation; 2013. http://cran.r-project.org/web/packages/MuMln/index.html.

39. Ruiz MO, Tedesco C, McTighe TJ, Austin C, Kitron U. Environmental and social determinants of human risk during a West Nile virus outbreak in the greater Chicago area, 2002. Int J Health Geogr. 2004;3:8.

40. Forsyth JE, Mutuku FM, Kibe L, Mwashee L, Bongo J, Egemba C, et al. Source reduction with a purpose: mosquito ecology and community perspectives offer insights for improving household mosquito management in coastal Kenya. PLoS Negl Trop Dis. 2020;14:e0008239.

41. Vannavong N, Seidu R, Stenström T-A, Dada N, Overgaard HJ. Effects of socio-demographic characteristics and household water management on Aedes aegyptiproduction in suburban and rural villages in Laos and Thailand. Parasites Vectors. 2017;10:170.

42. LaDeau S, Leisnham P, Biehler D, Bodner D. Higher mosquito production in low-income neighborhoods of Baltimore and Washington, DC: understanding ecological drivers and mosquitoborne disease risk in temperate cities. IJERPH. 2013;10:1505-26.

43. Samson DM, Archer RS, Alimi TO, Arheart KL, Impoinvil DE, Oscar R, et al. New baseline environmental assessment of mosquito ecology in northern Haiti during increased urbanization. $J$ Vector Ecol. 2015;40:46-58.

44. Kudom AA, Mensah BA. The potential role of the educational system in addressing the effect of inadequate knowledge of mosquitoes on use of insecticide-treated nets in Ghana. Malar J. 2010;9:256.

45. Healy K, Hamilton G, Crepeau T, Healy S, Unlu I, Farajollahi A, et al. Integrating the public in mosquito management: active education by community peers can lead to significant reduction in peridomestic container mosquito habitats. PLoS ONE. 2014;9:e108504.

46. Nasir S, Jabeen F, Abbas S, Nasir I, Debboun M. Effect of climatic conditions and water bodies on population dynamics of the dengue vector, Aedes aegypti (Diptera: Culicidae). J Arthropod Borne Dis. 2017;11:50-9. 
47. Overgaard HJ, Olano VA, Jaramillo JF, Matiz MI, Sarmiento D, Stenström TA, et al. A cross-sectional survey of Aedes aegypti immature abundance in urban and rural household containers in central Colombia. Parasit Vectors. 2017;10:356.

48. Cordeiro R, Donalisio MR, Andrade VR, Mafra AC, Nucci LB, Brown JC, et al. Spatial distribution of the risk of dengue fever in southeast Brazil, 2006-2007. BMC Public Health. 2011;11:355.

\section{Figures}

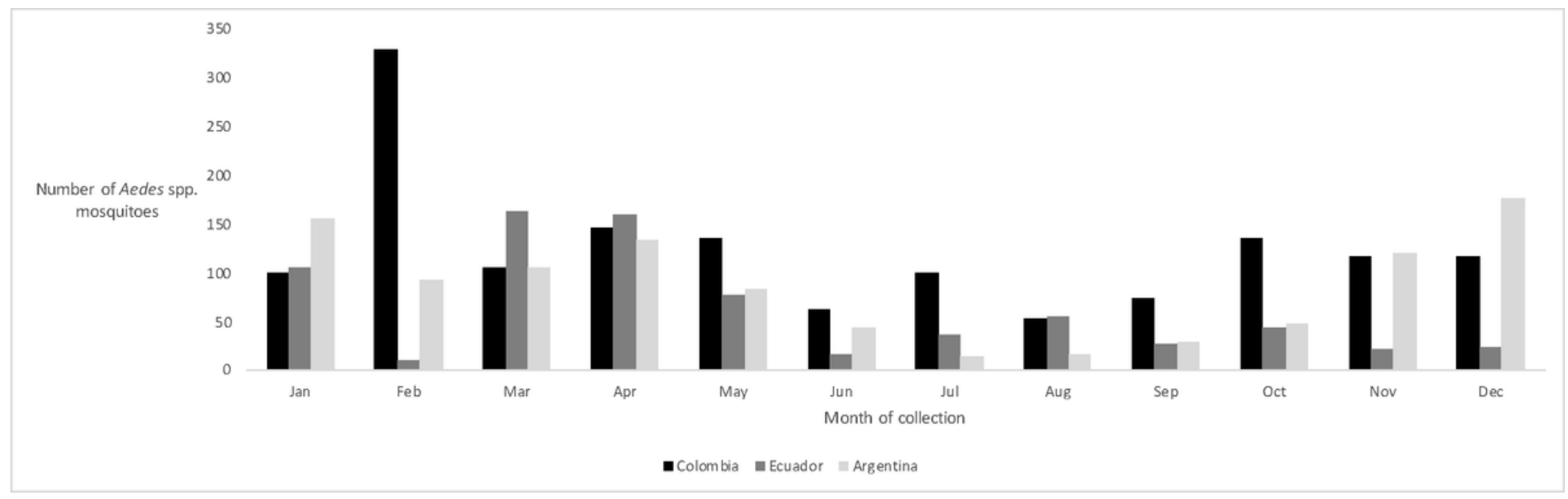

Figure 1

Number of captured mosquitoes identified as Aedes spp. by month of sampling (first three letter abbreviations) and study site in Ibagué, Colombia; Manta, Ecuador; and Posadas, Argentina.

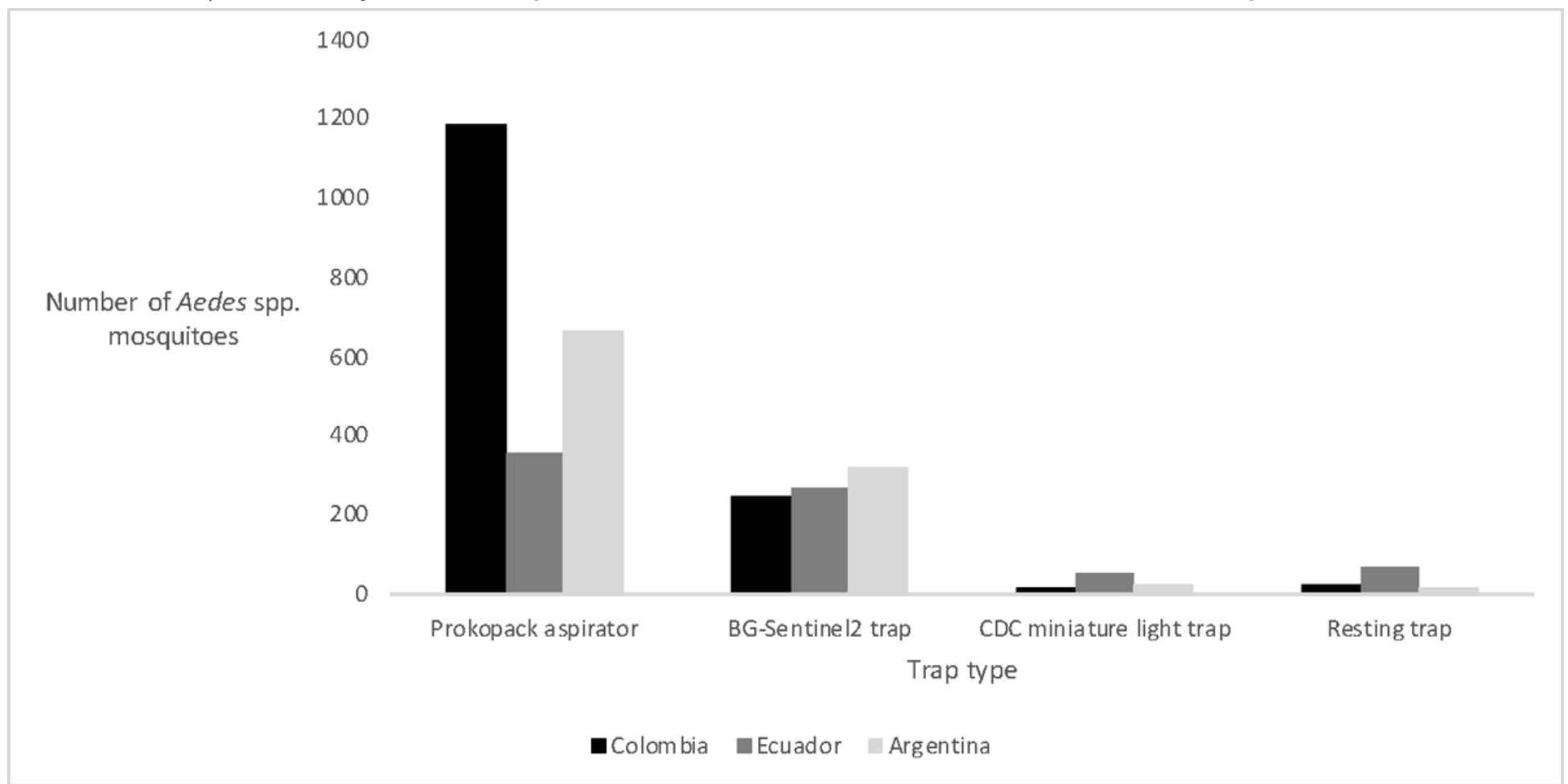

Figure 2 
Number of captured mosquitoes identified as Aedes spp. by method of capture and study site in Ibagué, Colombia; Manta, Ecuador; and Posadas, Argentina.

300

250

200

Number of households

150

100

50

0

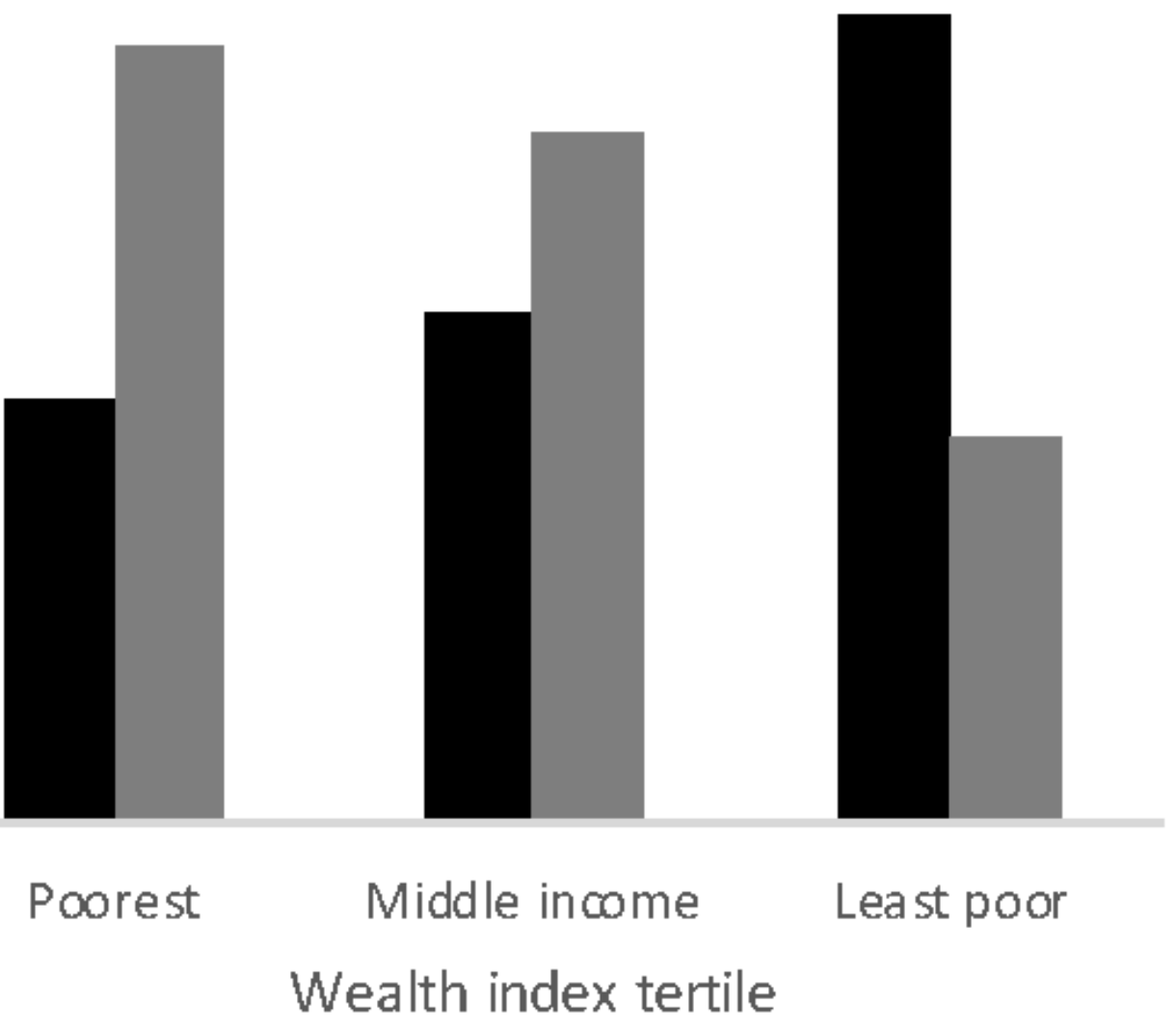

- Perceived high socioeconomic status

Perceived low socio-econom ic status

\section{Figure 3}

Number of households included in the study by wealth index tertile and whether they are located in a neighborhood that was perceived high or low socio-economic status prior to the study. 


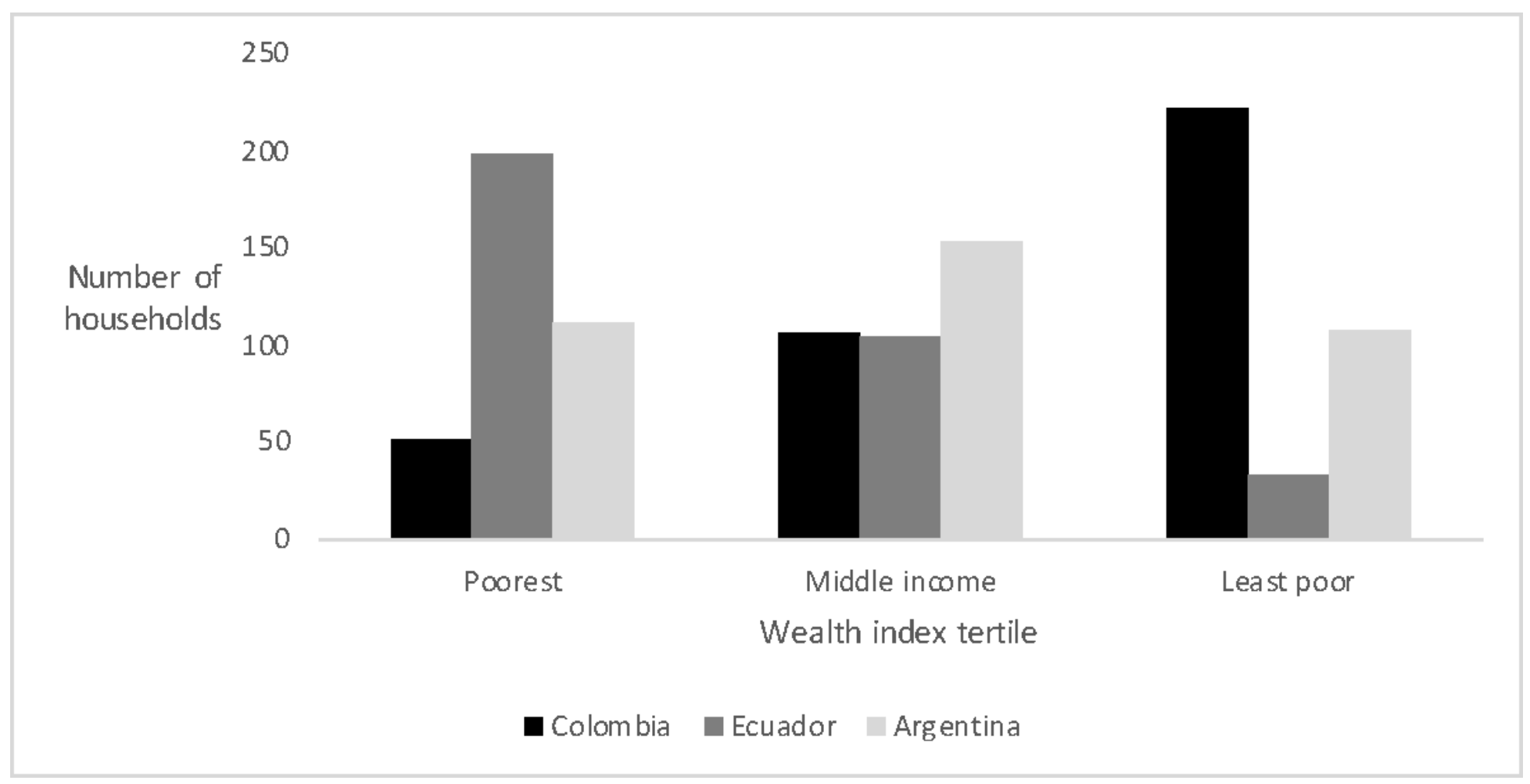

\section{Figure 4}

Number of households included in the study by wealth index tertile and study site in Ibagué, Colombia; Manta, Ecuador; and Posadas, Argentina. 


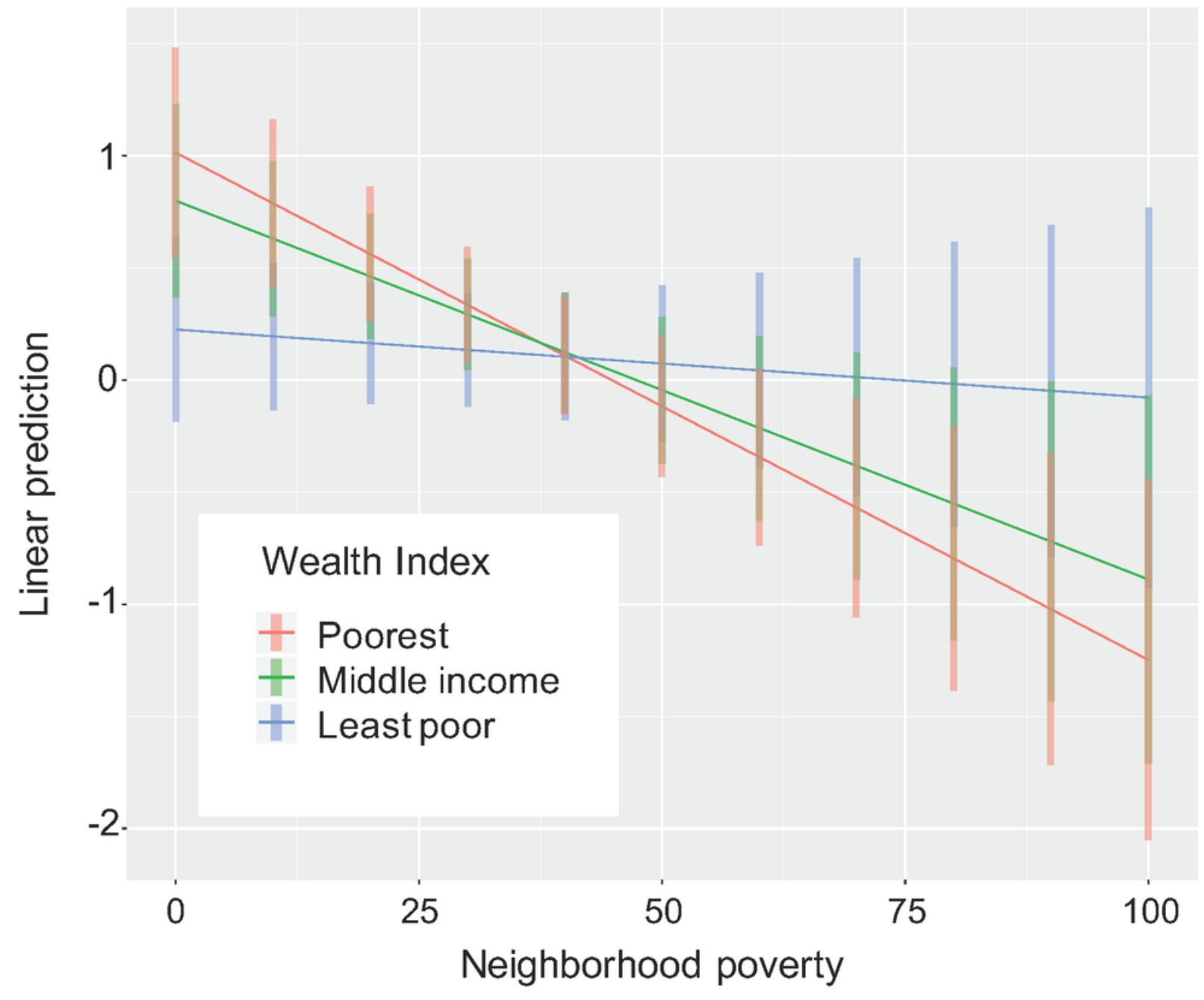

Figure 5

Graph showing the interaction effect of wealth index (fitted line and standard error for the three tertiles as in Legend) and neighborhood poverty (percent households of the poorest wealth index tertile) on linear prediction of household female Aedes spp. mosquito abundance.

\section{Supplementary Files}

This is a list of supplementary files associated with this preprint. Click to download.

- AdditionalFile1.pdf

- AdditionalFile2.docx

- AdditionalFile3.docx

- P1050642.jpg 